\title{
A Case of Septal Abscess and Sphenoid Sinusitis after Dental Implant
}

\author{
Jun Lee, Su Jin Kim, and Myoung Su Choi \\ Department of Otorhinolaryngology-Head and Neck Surgery, Eulji University Medical Center, Eulji University School of Medicine, \\ Daejeon, Korea
}

\section{임플란트 시술 후에 발생한 비중격 농양 및 접형동 부비동염 1예}

이 준·김수진 · 최명수

을지대학교 의과대학 이비인후과학교실

\author{
Received November 16, 2017 \\ Revised December 21, 2017 \\ Accepted January 3, 2018 \\ Address for correspondence \\ Myoung Su Choi, MD \\ Department of Otorhinolaryngology- \\ Head and Neck Surgery, \\ Eulji University Medical Center, \\ Eulji University School of Medicine, \\ 95 Dunsanseo-ro, Seo-gu, \\ Daejeon 35233, Korea \\ Tel $+82-42-611-3129$ \\ Fax $+82-42-611-3136$ \\ E-mail mschoi@eulji.ac.kr
}

A nasal septal abscess results from the collection of purulent fluid between the cartilage of bony septum and overlying mucoperichondrium or mucoperiosteum. Unless early diagnosis and surgical treatment are performed, serious complications such as cavernous sinus thrombophlebitis, sepsis, and saddle nose may occur. We report a case of septal abscess and sphenoid sinusitis that occurred after dental implant. A 74-year-old female with diabetes and liver cirrhosis was referred to the hospital for management of rapidly aggravated perinasal pain, nasal obstruction, and headache. The patient had undergone dental implant in the right upper incisor area 6 days ago. A CT revealed septal abscess and bilateral sphenoid sinusitis. The patient was operated upon to drain septal abscess, and both sphenoid sinuses were opened widely.

Korean J Otorhinolaryngol-Head Neck Surg 2019;62(4):242-5

Key Words Abscess - Dental implant · Immunocompromised host · Nasal septum · Sphenoid sinusitis.

\section{서 론}

비중격 농양은 연골성 또는 골성 비중격과 이를 덮고 있는 연골막이나 골막 사이에 발생한 농양을 말한다.,2) 발열, 코 막힘, 전두통, 비배부 동통과 압통, 전신쇠약감, 비루 등의 증 상이 나타날 수 있다. 비중격 농양은 드물지만, 해면정맥동혈 전증(cavernous sinus thrombophlebitis), 뇌농양, 뇌막염, 패 혈증 등의 위중한 합병증으로 발전할 수 있어 비과적 응급질 환 중에 하나이다. ${ }^{1,2)}$ 대부분 외상이나 수술 후 발생한 비중격 혈종의 화농으로 인해 발생하는 경우가 많다. 드물지만, 비전 정염이나 코의 농가진, 비부비동염 같은 코의 염증성 질환에 의해서도 발생할 수 있다. ${ }^{1,2)}$ 치성 감염에 의해 비중격 농양이

This is an Open Access article distributed under the terms of the Creative Commons Attribution Non-Commercial License (http://creativecommons.org/licenses/by-nc/4.0) which permits unrestricted non-commercial use, distribution, and reproduction in any medium, provided the original work is properly cited.
발생한 경우도 보고된 적이 있으나,3) 치과 임플란트 시술이 원 인이 되는 경우는 아직 보고된 바가 없다. 저자들은 위 절치부 위에 임플란트 시술 후 발생한 비중격 농양 및 양측 접형동염 1 예를 보고하는 바이다.

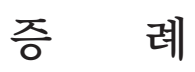

당뇨, 간경화의 병력이 있는 74 세 여자 환자가 5 일 전 시작 된 코의 통증, 코막힘, 점차 악화되는 두통을 주소로 내원하 였다. 과거에 우측 위 측절치 염증으로 발치하였으며, 내원 6 일 전에 발치 부위 잇몸에 임플란트 고정체(fixture) 시술을 받 았다. 이학적 검사상 코와 주변 부위에 심한 압통을 호소하 였고, 전비경 검사상 미단부 비중격은 양측으로 심하게 부어 있으며, 촉진 시 파동이 느껴졌다(Fig. 1). 환자는 비중격 농양 의심 하에 입원하여 응급 혈액검사를 시행하였다. 백혈구 수 


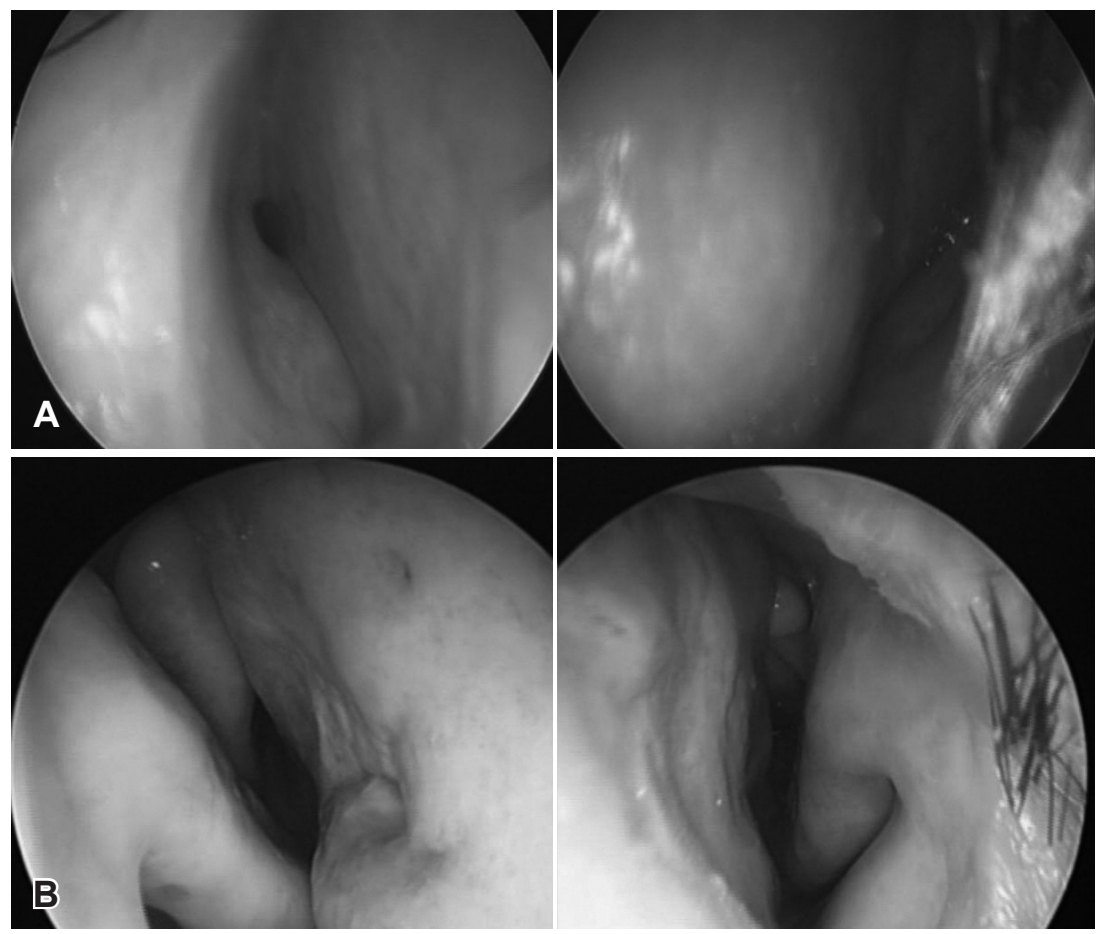

Fig. 1. Preoperative (A) and postoperative (B) view of nasal septal abscess.

치는 $17130 / \mu \mathrm{L}$ 으로 증가하였으며, 중성구 비율이 $85.1 \%$ 로 증 가한 상태였고, C-반응성 단백은 $9.32 \mathrm{mg} / \mathrm{dL}$ 로 높게 측정되 었다. 당화혈색소는 $8.2 \%$ 로 증가하였으며, 혈액 간 기능 검사 수치는 정상범위에 있었다. 타 병원에서 시행한 부비동 CT상 연골성 비중격 부위에 농양이 확인되었으며 골성 비중격 부 위에도 소량의 농양이 이어져, 양측 접형동 입구 부위까지 이 어지고 있었으며, 양측 접형동 내부에도 연부조직 음영이 확 인되었다(Fig. 2), 환자는 응급으로 전신마취하에 절개 배농 술을 시행받았다. 18 게이지 주사기로 비중격 미단부위를 흡 인하여 $1 \mathrm{cc}$ 가량의 농을 얻어 균 동정을 시행하고, 반관통절 개를 시행하여 우측 비점막을 거상한 후 남은 농을 배농하였 다. 괴사가 의심되는 연골성 비중격은 최대한 제거하였고, 항생 제가 포함된 세척액으로 농양 내부를 충분히 세척한 후, 우측 비중격 점막 하단부위에 배액관을 삽입하였다. 내시경 하에 양측 접형동 개구부를 탐색 후, 넓게 개방하여 농을 배출한 뒤 수술을 종료하였다. 수술 다음 날 치과에 협진을 시행하 였고, 전상악 부위에 시술된 임플란트 고정체가 바깥쪽 피질 골 층을 약간 벗어나 있는 것이 확인되었다(Fig. 2). 치과에서 는 항생제 치료 후 3 4일 이후에 병변을 재평가하기로 하였다. 수술 시 시행한 균 배양 검사에서는 Klepsiella pneumoniae가 동정 되었고 입원 후 사용하던 경험적 항생제(Augmentin)에 감수성이 있어 그대로 유지하였다. 절개 배농 후, 환자의 임상 증상은 상당히 호전되었으나, 환자가 코 부위 통증과 두통을 지속적으로 호소하여, 치과에 재의뢰하여 임플란트 고정체를
제거하였다. 임플란트 고정체를 제거하는 중에 잇몸 점막은 붓고 쉽게 출혈이 나는 염증성 점막소견을 보였고, 고정체는 잇몸뼈에서 단단히 고정되어 있지 않고 상당히 흔들리는 양 상을 보였다. 이후 환자의 증상은 확연히 호전되어 1주간 항 생제 치료 유지한 후 배액관을 제거하고 퇴원하였다. 퇴원 후 3주째 비중격의 부종은 호전되었으나 상당한 정도의 안비 (saddle nose)가 확인되었다. 환자는 큰불편을 호소하지 않았 고, 외형과 관련된 수술은 원치 않아 경과관찰 중이다.

\section{고 찰}

비중격 농양은 여러 기전으로 생길 수 있다. 첫 번째는 부비 동염이나 비절 등 비점막 질환의 직접적인 감염으로 발생할 수 있다. ${ }^{4)}$ 두 번째는 비중격 혈종에 의한 이차적인 화농이다. 비중격 혈종은 대개 코의 외상이나, 비과적 수술 후의 합병증 으로 발생하며, Ambrus 등 ${ }^{2}$ 에 의하면 비중격 농양의 $75 \%$ 가 여기에 해당한다고 한다. 세 번째는 치성 감염이다. ${ }^{3)}$ 치성 감 염은 이비인후과의 비과 질환과 여러 부분에서 연결되어 있어, 비과적 질환의 원인 감별 시 간과하지 말아야 할 중요한 요인 이다. 네 번째는 외상이나 감염의 증거가 없이 자발적으로 발 생한 경우이다. ${ }^{5)}$ 특히 면역이 저하된 환자에서는 기회감염을 통해 발생할 수 있다고 알려져 있다. ${ }^{6)}$ 이러한 기전 중 이번 증례는 치아 임플란트와 관련된 치성 감염이 원인으로 추정 되고 있다. 치아 임플란트 시술 건수는 최근 노인 인구의 증가 

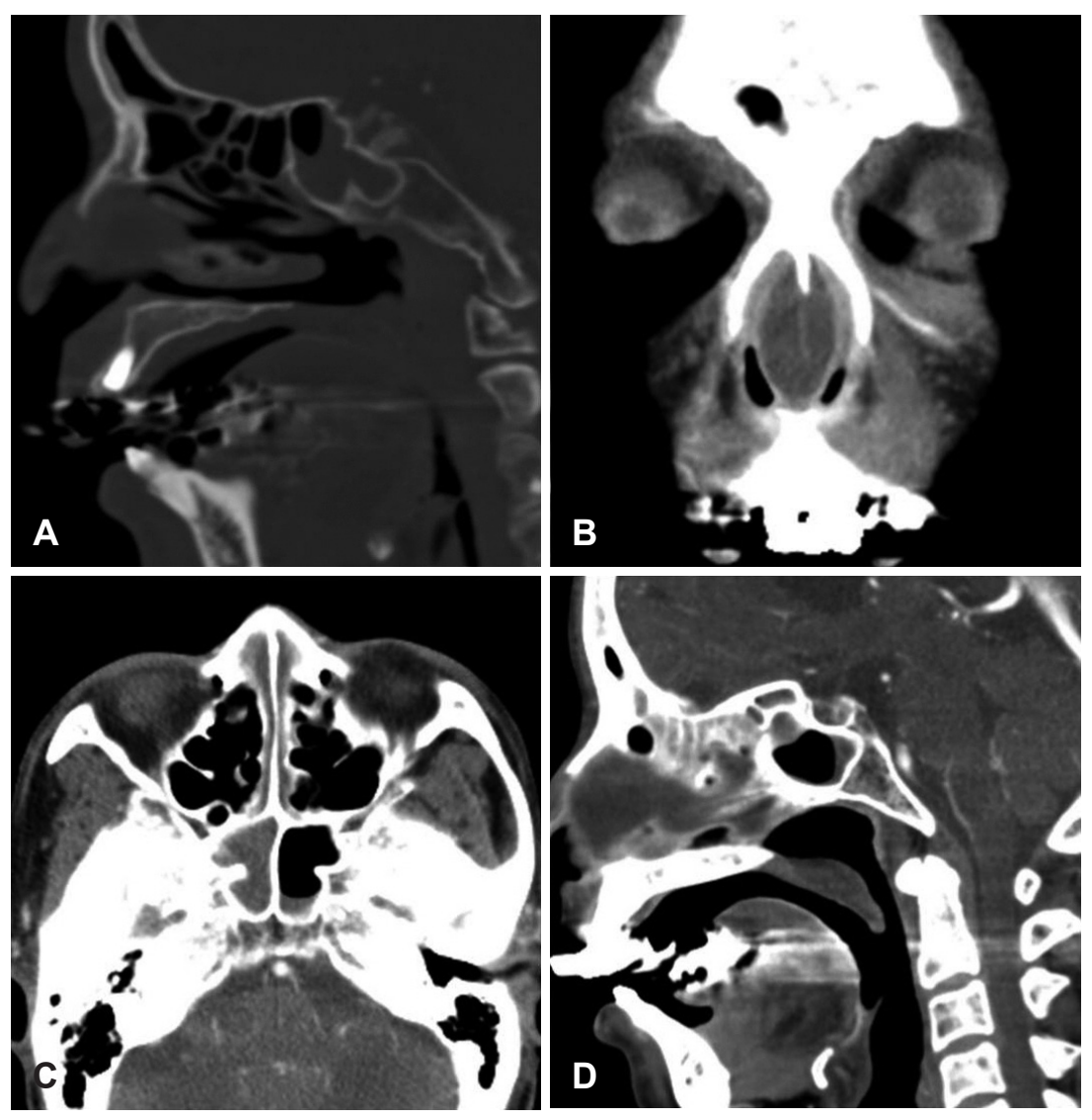

Fig. 2. CT imaging of nasal septal abscess and sphenoid sinusitis after dental implant. Dental fixture placed on the lateral incisor area (A). Septal abscess in coronal CT view showing central low density (fluid collection) with peripheral enhancement (B). Nasal septal abscess extending into the sphenoid sinus complicating sinusitis via septal mucosa. Axial view (C), Sagittal view (D).

와 더불어 느는 추세이며, 이와 더불어 임플란트 관련 합병증 도 증가하고 있다.7) 임플란트와 관련된 부비동염, 상악동 내로 돌출된 임플란트 등은 그간 보고 되었으나, ${ }^{7)}$ 이번 증례처럼 임플란트가 비중격 농양의 원인으로 밝혀진 경우는 저자들 이 알기로는 국내외에 아직 없었다.

치료 후 환자에게서 상당한 정도의 안비가 관찰되었다. 비 중격 연골은 덮고 있는 비중격 점막에 의해서 영양공급을 받 기 때문에 비중격 혈종이나 농양에 의해 비중격 점막과 차단 이 되면 허혈에 빠지게 되고 또한, 혈종이나 농양의 압박에 의해 2 3일 이내에 괴사에 빠진다고 알려져 있다.,2) 이렇게 괴사에 빠진 연골은 가능하면 충분히 제거해야만 하고, 남겨 두었을 경우에는 세균감염의 배지가 될 수 있다. 본 증례의 환자는 고령으로 미용적 치료를 원하지 않았기 때문에 추가 치료는 시행하지 않았다. 하지만, 괴사한 비중격 연골 부위는 추후 섬유성 조직으로 대치되고 흥터화 반응으로 협착이 진 행되면 코막힘을 유발할 수 있다. 즉, 미용적 문제뿐만 아니 라 기능적 문제가 생길 수 있으므로 염증이 충분히 가라앉 은 후 자가연골을 이용한 비중격 재건술을 고려해야 한다. ${ }^{8)}$

비중격 농양을 일으키는 원인균으로는 Staphylococcus aureus, Streptococcus pneumoniae, beta-hemolytic group A Streptococcus, Haeophilus influenzae, 기타 혐기성 균으로
알려져 있고 ${ }^{2,3)}$ 이 중에서 Staphylococcus aureus가 가장 흔한 것으로 알려져 있다. 본 증례에서는 Klebsiella pneumoniae 가 검출되었으며, 이는 장내세균의 일종으로 구강 등에서도 발견될 수 있다." 이번 증례에서는 임플란트 시술 중 구강 점 막을 통해서 비중격에 감염되었을 수도 있고, 또는 임플란트 시술을 시행했던 병원 내 감염이 원인일 수도 있다. 본 증례에 서는 환자가 고령, 당뇨, 간경화 등 면역기능 저하의 요인을 갖 고 있어 임플란트와 관련되어 감염에 취약하였을 것으로 보 인다. Shah 등 ${ }^{6}$ 은 5 명의 면역저하 환자에서 발생한 비중격 농양 환자 중에서 절개 및 배농, 내시경하 사골동 및 접형동 수술을 시행하였음에도, 진균감염이 병발하여 사망한 사례 1 예를 보고하여 면역기능이 저하된 환자에서는 조기진단과 적절한 치료가 필요함을 강조하였다. 국내에서도 신장이식 후 면역 억제 치료를 받은 환자에서 외상없이 발생한 진균성 비 중격 농양의 증례를 보고한 바 있다. ${ }^{10)}$ 측절치 임플란트 후에 발생한 비중격 농양은 점막을 통해 후방으로 접형동 전벽과 직접적으로 이어져 있어서 접형동염이 동반될 수 있다(Fig. 2). ${ }^{11)}$ 또는 반대로 접형동염의 합병증으로 비중격 농양이 발 생한 사례도 있다. ${ }^{12)}$ 본 증례에서는 비중격 농양에 접형동염 이 합병된 것으로 생각되었고, 환자의 나이와 내과적 병력, 두 통 등의 악화되는 임상 증상 때문에 비중격 농양 절개 배농 
술 이외에도 내시경하 접형동 개구술을 동시에 시행하였다.

저자들은 이번 증례를 통해서 비중격 농양의 드문 원인으 로 임플란트를 포함한 치성 감염도 고려할 필요가 있으며, 신 속하게 원인을 진단하고 적극적인 치료를 하는 것이 합병증 을 예방하는 데 도움이 될 것으로 생각한다.

\section{ORCID}

Myoung Su Choi https://orcid.org/0000-0003-4553-7808

\section{REFERENCES}

1) Canty PA, Berkowitz RG. Hematoma and abscess of the nasal septum in children. Arch Otolaryngol Head Neck Surg 1996;122(12):1373-6.

2) Ambrus PS, Eavey RD, Baker AS, Wilson WR, Kelly JH. Management of nasal septal abscess. Laryngoscope 1981;91(4):575-82.

3) da Silva M, Helman J, Eliachar I, Joachims HZ. Nasal septal abscess of dental origin. Arch Otolaryngol 1982;108(6):380-1.

4) Huang PH, Chiang YC, Yang TH, Chao PZ, Lee FP. Nasal septal abscess. Otolaryngol Head Neck Surg 2006;135(2):335-6.

5) Beck AL. Abscess of the nasal septum complicating acute ethmoiditis. Arch Otolaryngol 1945;42:275-9.

6) Shah SB, Murr AH, Lee KC. Nontraumatic nasal septal abscesses in the immunocompromised: etiology, recognition, treatment, and sequelae. Am J Rhinol 2000;14(1):39-43.

7) Jeong KI, Kim SG, Oh JS, You JS. Implants displaced into the maxillary sinus: a systematic review. Implant Dent 2016;25(4):547-51.

8) Hellmich S. Reconstruction of the destroyed septal infrastructure. Otolaryngol Head Neck Surg 1989;100(2):92-4.

9) Podschun R, Ullmann U. Klebsiella spp. as nosocomial pathogens: epidemiology, taxonomy, typing methods, and pathogenicity factors. Clin Microbiol Rev 1998;11(4):589-603.

10) Jeong JH, Kim HO, Lee YS, Chung JH. A case of fungal nasal septal abscess in the immunocompromised patient. Korean J Otorhinolaryngol-Head Neck Surg 2008;51(11):1061-4.

11) Gradoni P, Fois P. Nasal septal abscess complicating isolated acute sphenoiditis: case report and literature review. B-ENT 2010;6(4): 303-5.

12) Pang KP, Sethi DS. Nasal septal abscess: an unusual complication of acute spheno-ethmoiditis. J Laryngol Otol 2002;116(7):543-5. 